\title{
Does innovation stimulate employment? Evidence from China France, Germany, and the Netherlands
}

\author{
Jun Hou ${ }^{1}$, Can Huang ${ }^{2}$, Georg Licht ${ }^{3}$, Jacques Mairesse ${ }^{45}$, Benoît Mulkay ${ }^{7}$, Pierre \\ Mohnen $^{68}$, Bettina Peters ${ }^{310}$, Yilin $\mathrm{Wu}^{9}$, Yanyun Zhao ${ }^{9}$, Feng Zhen ${ }^{9}$ \\ ${ }^{1}$ University of Lincoln, ${ }^{2}$ Zhejiang University, ${ }^{3} \mathrm{ZEW},{ }^{4} \mathrm{ENSAE},{ }^{5} \mathrm{NBER},{ }^{6} \mathrm{UNU}-\mathrm{MERIT}$, \\ ${ }^{7}$ Université de Montpellier, ${ }^{8}$ Maastricht University, ${ }^{9}$ Renmin University of China, ${ }^{10}$ University of \\ Luxembourg
}

August 2018

\begin{abstract}
This paper tests whether product and process innovations increase employment in three European countries - France, Germany and the Netherlands - and in the People's Republic of China on the basis of the same underlying theoretical framework and comparable harmonized micro data. The data pertain to the period 2002-2004 and cover the manufacturing and services industries in the three European countries, and to the period 1999-2006 and only the manufacturing industries in China. Process innovation does not play a significant role whereas non-innovation related efficiency improvements in the production of unchanged products tend to reduce employment. In contrast, product innovation stimulates employment, the compensation effect via increased demand dominating the displacement effect. The net effect of product innovation and the net growth in total employment are comparable in the two regions.
\end{abstract}

The research underlying in this paper was conducted by three European research institutions (UNU-MERIT in the Netherlands, LEREPS in France, ZEW in Germany) and two Chinese institutions (Chinese Academy of Social Sciences - CASS- and Renmin University of China). It was funded by the CO-REACH (Co-ordination of Research between Europe and China) network of 16 European S\&T policy and funding organizations, which was supported by the European Commission. The title of the project was "Employment, innovation and welfare: a comparative study of Europe and China". We thank an anonymous referee for his/her constructive comments and Giovanni Dosi for his unwavering encouragement. 


\section{Introduction}

Policy makers are torn between two objectives: promote innovation to increase the level of income, and ultimately of well-being, and increase employment to provide all workers with a source of income and a sense of dignity. To some extent the two objectives go hand in hand, in practice however increasing innovation can yield productivity growth by decreasing the level of employment. This fear of losing jobs with the advent of machines replacing humans was already felt by the English textile workers in the early days of industrialization. The same dilemma still holds nowadays in the fourth industrial revolution, the digital age, where computers and robots may do the hard work that was previously done by man.

This paper aims to test whether innovation, in the form of new products or new methods of production, does indeed reduce the demand for labor, or whether on the contrary the net effect of innovation increases employment.

In the short run, it is quite likely that new machines that can do the job performed by humans will replace labor and reduce employment. It may also be that the new machines require a different kind of skill leading to a replacement of some workers by others. Because of search and adjustment costs it may also take some time to find the workers with the right skills and therefore there will be some frictional unemployment in the short run. In the long run, however, the new methods of production may be more productive, increase the firms' competitiveness and thereby sales, expected growth in future sales and indirectly employment. If innovation takes the form of new products, there could be a cannibalization in the short run, new products merely replacing old products, with little, if any, effect on employment, it all depending on the labor requirement and productivity in the production of the old and the new products. If the demand for the new products is sufficiently strong and the firm can meet this demand, especially if the average production costs decrease, firms do not adjust their profit margins, and consumers are price elastic, then there may even be an increase in employment in the medium to long term. The final answer is therefore a matter of relative productivities, agents' behavior and price sensitivities.

We examine this issue at the micro level over a three-year period for France, Germany and the Netherlands using the Community Innovation Survey (CIS) harmonized micro data for manufacturing and services industries on innovation occurrence, and in the case of product innovation, the share of total sales due to new products. We also examine the issue on the basis of similar micro-data for one giant Asian country - the People's Republic of China as concerns product innovation in manufacturing industries. We thought that it was particularly interesting to be able to implement the comparison with China in view of its huge differences with the three European countries, in spite of lack of information on process innovation occurrence and the limitation to manufacturing. 
We apply the same theoretical model to the data on the four countries, and we even try to use the same identification methods to uncover the estimates of the model. The underlying model is borrowed from the Harrison et al. (2014) framework.

\section{Literature}

The debate about the potential damaging effect of innovation on employment is reminiscent of the Luddite movement in Nottingham at the dawn of the industrial revolution, where textile workers destroyed newly introduced machines in the fear of losing their job. And the discussion has been going on since then. Nowadays the concern is that computerization could lead to massive unemployment as predicted by Frey and Osborne (2017).

That innovation can have, and probably has, an immediate negative effect on employment in certain lines of business is largely accepted. The real issue is whether there are sufficiently strong compensation mechanisms that counteract the initial job destruction caused by innovation (see Pianta (2005), Vivarelli (2014), Calvino and Virgillito (2018) for a more detailed discussion). Process innovations are intended to be cost-saving, and labor is one of the main cost components. Process innovation is thus likely to be labor-saving. This could lead to wage reduction (because of decreased net demand) and productivity improvements, possibly followed by price reductions, and depending on the demand elasticity, to higher demand on the output market and renewed demand on the labour market. Besides the price effect, there is also a possible income effect that could raise or lower the demand for labor, as wage earners see their income decrease and capitalists see theirs increase. The profit from labor-saving innovations can also be reinvested, refueling the demand for labor. Another compensation mechanism is that more labour will de demanded in the capital goods market to produce the labor-saving machines in the sectors where they are sold. The story is even more blurred regarding product innovations. New goods will create jobs if there is a latent demand for these new goods, but the new goods may also simply act as substitutes for some old goods. The production for the new goods may moreover be less labor-intensive than for the old goods. A new good or technology may, however, just be the beginning of a whole new generation of innovations. The digital technology is a case in point.

Since the end effect of innovation on employment is complex and theoretically ambiguous, many studies have tried to examine this issue. Two major differences between these studies are the time length investigated and the level of aggregation. It is obvious that the compensation mechanisms may more fully roll out their effect if a sufficient period of time is allowed. Some effects like technological spillovers may take longer than others (market stealing). A study at the

micro level will reveal the own direct and indirect effects, as a reduced form model, but probably not allow the identification of particular compensation mechanisms. It may, however, 
differentiate between types of innovations and types of employment. A study at the sector level has the benefit to include in the analysis the competitive (business-stealing) effects between firms within an industry so as to assess the final effect for all firms in a given industry. A study at the macro level includes the inter-sectoral shifts in demand and compensation effects.

The present study is based on micro data. The innovation surveys contain information on the changes in sales (over a three-year period) that are due to products that existed already and products that were introduced during this period. It also contains information on the occurrence of process innovation during this period. The idea then is to examine how much of the growth in employment can be attributed to the production of new products and to the introduction of process innovation. These two effects include some of the compensating effects due to price reductions, reinvested profits and possibly wage declines, although we cannot identify them.

Two excellent surveys of the empirical evidence obtained from micro data are those of Vivarelli (2014) and Calvino and Virgillito (2018). There is no point in repeating their literature overview. ${ }^{1}$ In summary, they report that the studies that used R\&D and patent data as indicators of innovation generally conclude to a positive association with employment growth especially in high-tech sectors/firms. Those that differentiate between product and process innovations in general find a positive effect for product innovations but mixed results for process innovations. For instance those that follow the Harrison et al. (2014) model, which we adopt in this study, (Hall, Lotti and Mairesse, 2008, Benavente and Lauterbach (2008), Peters et al. (2014)), find that product innovations increase employment - i.e. the compensating mechanism outweighs the immediate labor displacement effect and the cannibalization effect on old products - but mostly insignificant and sometimes significantly negative effects of process innovation, e.g. during recession or in services (Peters et al., 2014). These models do not account for persistence in employment. Dynamic labor demand equations have been estimated by Lachenmaier and Rottmann (2011). They find a stronger and more immediate positive effect for process innovations than for product innovations, except for product innovations for which patent applications are filed, and a more immediate effect for innovation output than for innovation expenditure. Bianchini and Pellegrino (2017) do not find a highly significant immediate effect of product and process innovation on employment growth, but well a strongly positive effect of persistent product (not process) innovation. Evangelista and Vezzani (2012) show that process innovation is associated with employment reduction only when it is concurrent with organizational innovation.

What do we expect to find? Since we use the Harrison et al. (2014) model on cross-section data for countries with pretty similar industrial policies (e.g. price regulations) and preferences (demand elasticities), we do not expect to find for France and Germany results very different

\footnotetext{
${ }^{1}$ Vivarelli (2014) and Calvino and Virgillito (2018) also cover the evidence obtained from macro and industry data. Since this study is based on micro data, we concentrate on the findings obtained with micro data. See also Ugur, Churchill and Solomon (2018) for a meta-regression analysis of empirical studies on the innovation-employment relationship.
} 
from those in Harrison et al. (2014) and Peters et al. (2014). For the Netherlands, there is no previous evidence and firms are of smaller size than in Germany and France (see table 2). But again, it would be surprising to see a different picture from France and Germany. For China, however, we are in a different ballgame. First, we have panel data, second, we have a much larger sample, and third, the economic environment is quite different from Europe.

\section{Model}

The model by Harrison et al. (2014) is summarized in the paper by Crespi, Tacsir and Pereira (in this issue). In essence, labor demand is derived from the first-order condition of a (static) cost minimization problem, with only one type of labor, where two types of products, old and new products, are considered, input prices are supposed not to change over a three-year study period and are the same for old and new products (it is in any case difficult to get firm level price data) and the returns to scale of the underlying production function are constant. Changes in the demand for labor can thus be ascribed to changes in the efficiency of production and in the level of output. The particularity of this model is that it allows the decomposition of total production into the production of old products, which existed already three years before, and new products, which did not exist then. The production of each generation of products has its own efficiency.

The equation of employment growth can be viewed as a simplified structural or reduced form equation of a micro behavioral model, which essentially allows to account for the growth of employment in terms of four components: the first and second due respectively to the nonprocess and the process innovation related productivity growth in the production of old products, the third and fourth due respectively to the increases in sales of old and of new products. For lack of additional information on the sources of firm labor demand, this equation cannot explicitly deal with competition among firms in prices or innovation, innovation externalities and production complementarity or substitution effect, and thus cannot separately identify price elasticities, profit margins and cost reductions. Indeed, firm A may demand less labor because its competitors have introduced competing products and reduced the prices of products similar to its own. However, it could also be the case that firm A benefits from the introduction by other firms of new products that might be complementary to its own products. Finally increases in efficiency may be the result of deliberate firm $R \& D$ investment or be the results of positive externalities from R\&D conducted elsewhere. Moreover, the equation does not consider firm entry and exit, which may increase or decrease overall output supply and prices and affect indirectly employment at the individual firm level.

The econometric difficulty comes from measurement problems and simultaneities. To be more precise, the reduced form regression equation is written as

$$
l-g_{1}=\alpha_{0}+\alpha_{1} d+\beta g_{2}+u
$$


where $l$ measures the growth in employment, $g_{1}$ the growth in the production of old products (defined as the usual rate of growth of the sales ratio of old products in the study period to total products in the previous period), and $g_{2}$ is the sales ratio of new products in period to old products in period $\mathrm{t}-1$, which can be regarded as the growth in sales of new products. $d$ is a dummy variable that indicates the occurrence of process innovation in the study period when it is not accompanied by product innovation. As shown in Table 1 below, product and process innovation occur in the same period, and thus to be able to identify the effect specific to process innovation, we estimate the effect of process innovation for old products only. ${ }^{2}$

The error term in the equation $u$ stands for the usual difference in productivity shocks unobserved by the econometrician, which can be partly known to the firm when it makes its innovation decisions and partly unanticipated. The coefficients $\alpha_{0}, \alpha_{1}$ and $\beta$ represent for $\alpha_{0}$ the efficiency improvements in the production of old products not related to process innovation and the resulting decrease in employment, for $\alpha_{1}$ the efficiency improvement and employment decline due to process innovation only, and for $\beta$ the efficiency in producing old relative to new products, with $\beta$ positive, and higher or lower than 1 if new products are produced respectively less or more efficiently than old products.

As stressed in Harrison et al. (2014) and Crespi et al. (in this issue), to the extent that productivity shocks are correlated with innovation, they lead to downward biased estimates of $\alpha_{1}$ and $\beta$ if estimated by ordinary least squares. Another sort of endogeneity problem may be due to the absence of good firm-level output deflators for old and new products, and hence the fact that output is measured in nominal terms instead of being properly measured in real terms. Again it can be shown that the presence of inflation leads to a downward bias in the two coefficients (on this point, see also Lotti et al., 2008). The estimation strategy will thus be i) to find instrumental variables correlated with product innovation $g_{2}$ but not with the error term consisting of unanticipated productivity shocks and unobserved price differences between new and old products and ii) to use industry deflators to measure real output of old products to moderate the attenuation bias due to inflation.

\footnotetext{
${ }^{2}$ The fact that process innovation is only measured by a dummy variable indicating that some process innovation took place in a three-year period and that product innovation often occurs jointly with the introduction of new products makes it difficult to estimate accurately the effect of process innovation on employment. Evangelista and Vezzani (2012) and Harrison et al. (2014) introduce separate combinations of innovation types in the employment equation. It is, however, not easy to identify the impact of different kinds of innovation, especially when taking their endogeneity into account. Actually, as Harrison et al. (2014) show, if part of the error term is due to unmeasured price inflation which could be enmeshed with process innovation, even the coefficient of the process innovation dummy could be affected by errors in variables. Cirera and Sabetti (in this issue) try to dissociate from the coefficient of product innovation the portion that is due to process innovation, automation in particular, and possibly organizational innovation. Barbieri, Piva and Vivarelli (in this issue) introduce an input measure (and not an output measure) of process innovation, namely the innovation expenditure devoted to the acquisition of machinery, equipment and software.
} 


\section{Data}

The model has been estimated on micro data over the period 2002-2004 for the manufacturing and business service industries separately in the Netherlands, France, Germany and only for manufacturing industries in China. In Europe, the data come from the harmonized Community Innovation Surveys (precisely CIS-4) and are thus quite comparable. For China, similar firmlevel data information at the year level on production and product innovation occurrence and output in the CIS are provided by the annual industrial surveys organized by the China National Bureau of Statistics (covering all state-owned firms, as well as all private and foreign firms with sales higher than 5 million RMB). On the basis of this yearly information, as explained in great details in Mairesse et al. (2012), we have been able to construct for China product innovation occurrence and share of innovative output for the study period 2004-2006, comparable to the one obtained for the three European countries. We also considered five different variants by computing these variables in two different ways for the one year 2006 and the two year 20052006 and found that the respective size of the shares of old and new product greatly differed between them, as could be expected (See Tables 3 and 4). We have found accordingly that the corresponding magnitudes of the OLS and IV estimated elasticity $\beta$ of the growth rate of new product output $g_{2}$ and the resulting contributions to the employment growth rate decomposition differed substantially (see Tables 5 to 7).

The CIS-4 sampling design differs largely across the three European countries both because it is stratified under a certain firm size and does not cover the smallest firms. In Germany, the innovation survey is also voluntary, which explains a number of observations lower than in France and the Netherlands where it is mandatory. In France, the sample is almost twice as large in manufacturing as in services, whereas in the Netherlands it is the opposite. This has to do with the fact that in the CIS a stratified sample is used for small firms and a census for all firms above a certain size. The cut-off point above which all firms enter the sample is 50 employees in the Netherlands, 250 employees in France and 500 in Germany. Hence there are more small firms in the Dutch sample than in the French sample and even more so in the German sample ${ }^{3}$ (see also line 1 of table 2). For comparability, we have eliminated all firms with less than 10 employees in the three countries. Finally, for China, as already indicated, we have a census of all state-owned firms and of non-state-owned firms with sales higher than 5 million RMB, hence a bias towards state-owned firms and large and medium-sized firms.

The proportion of innovating firms (be it in products or processes) is substantially higher in Germany, one of the innovation-leading countries, especially in manufacturing. ${ }^{4}$ In comparison

\footnotetext{
${ }^{3}$ But due to the voluntary nature of the survey in Germany, not all of the firms with at least 500 employees are in the net sample.

${ }^{4}$ To a small extent the higher proportion of innovators is explained by the voluntary nature of the survey. To account for this, the German CIS conducts a non-response analysis. Results show that in CIS-4 the proportion of
} 
to the European countries, China has a low proportion of innovating firms, namely only $21 \%$ compared to $57 \%$ in France, $51 \%$ in the Netherlands, and $72 \%$ in Germany. There are roughly as many product innovators as process innovators, except in German manufacturing, where there are $10 \%$ more product innovators than process innovators. Most innovating firms innovate simultaneously in products and processes. The propensity to innovate is higher in manufacturing than in services.

Table 1: Number and distribution of firms w/t innovation in France (FR), The Netherlands (NL), Germany (DE), manufacturing and services, and China (CN), manufacturing

\begin{tabular}{l|l|l|l|l|l|l|l}
\hline & \multicolumn{3}{|l|}{ Manufacturing } & \multicolumn{2}{l}{ Services } \\
\hline & FR & NL & DE & CN & FR & NL & DE \\
\hline Number of firms & 4818 & 2161 & 1832 & 27059 & 2544 & 5692 & 1141 \\
\hline Distribution of firms & in \% & in \% & in \% & in \% & in \% & in \% & in \% \\
\hline Non-innovators & 43.1 & 49.2 & 27.7 & 79.2 & 60.7 & 72.1 & 44.7 \\
Innovators & 56.9 & 50.8 & 72.3 & 20.8 & 39.3 & 27.9 & 55.3 \\
Process innovators & 45.0 & 38.0 & 48.6 & - & 32.8 & 20.2 & 37.4 \\
Product innovators & 43.2 & 39.7 & 59.5 & 20.8 & 26.7 & 18.5 & 41.9 \\
\hline $\begin{array}{l}\text { Process innovators } \\
\text { only }\end{array}$ & 13.6 & 11.2 & 12.8 & - & 12.6 & 9.4 & 13.4 \\
$\begin{array}{l}\text { Product innovators } \\
\text { only }\end{array}$ & 11.9 & 12.8 & 23.7 & - & 6.5 & 7.8 & 17.9 \\
$\begin{array}{l}\text { Product and process } \\
\text { innovators }\end{array}$ & 31.3 & 26.8 & 35.8 & - & 20.2 & 10.7 & 24.0 \\
\hline
\end{tabular}

As table 2 indicates, the distribution of firms according to size (measured by the number of employees) is skewed to the left, the mean size being substantially above the median size. The average size of Chinese firms is comparable to the average size of the German firms. The French average size is higher than the Dutch average size because of a higher cut-off point separating stratified sample from census data. It is clear that the growth rates in sales and employment are lower for non-innovators than for the average firm and hence implicitly for the average 
innovating firm. The growth rates are also larger for process innovators than non-innovators implying that process innovators do more than just cutting on employment. By lowering costs, they also contribute to higher sales and hence employment. Among the innovators, the growth rates are larger for firms that innovate in products and processes than for process innovators only, except in the Netherlands. This is true for the mean as well as for the median figures.

Table 2: Employment in 2004, and average annual growth rates (in \%) in employment and sales: France, the Netherlands, Germany (2002-2004) and China (1999-2006), in manufacturing

\begin{tabular}{|c|c|c|c|c|c|c|c|c|}
\hline & & \multicolumn{2}{|c|}{ FR } & \multicolumn{2}{|c|}{ NL } & \multicolumn{2}{|c|}{ DE } & $\mathbf{C N}$ \\
\hline & & mean & median & mean & median & mean & median & Mean \\
\hline $\begin{array}{l}\text { Employment in } \\
2004\end{array}$ & Total & 310 & 84 & 159 & 50 & 487 & 85 & 497 \\
\hline $\begin{array}{l}\text { Employment } \\
\text { growth }\end{array}$ & $\begin{array}{l}\text { Total } \\
\text { Non-innovators } \\
\text { Only process } \\
\text { innovators } \\
\text { Product and process } \\
\text { innovators } \\
\end{array}$ & $\begin{array}{r}-0.56 \\
-1.17 \\
-0.04 \\
0.66 \\
\end{array}$ & $\begin{array}{l}-1.61 \\
-2.15 \\
-1.27 \\
-1.16 \\
\end{array}$ & $\begin{array}{r}-1.75 \\
-2.85 \\
1.51 \\
-1.16 \\
\end{array}$ & $\begin{array}{r}-1.96 \\
-2.67 \\
0 \\
\\
-2.27 \\
\end{array}$ & $\begin{array}{l}1.82 \\
0.11 \\
1.08 \\
\\
3.41\end{array}$ & $\begin{array}{r}0 \\
0 \\
0 \\
0.96 \\
\end{array}$ & 7.4 \\
\hline Sales growth & $\begin{array}{l}\text { Total } \\
\text { Non-innovators } \\
\text { Only process } \\
\text { innovators } \\
\text { Product and process } \\
\text { innovators } \\
\end{array}$ & $\begin{array}{l}4.50 \\
2.73 \\
4.87 \\
7.04 \\
\end{array}$ & $\begin{array}{l}3.36 \\
1.93 \\
\\
3.82 \\
\\
5.28\end{array}$ & $\begin{array}{r}8.30 \\
6.34 \\
11.03 \\
9.95 \\
\end{array}$ & $\begin{array}{r}5.96 \\
5.25 \\
6.63 \\
6.77 \\
\end{array}$ & $\begin{array}{r}11.25 \\
7.54 \\
13.47 \\
\\
14.11 \\
\end{array}$ & $\begin{array}{r}7.58 \\
4.65 \\
8.03 \\
10.12 \\
\end{array}$ & $\begin{array}{c}39.6 \\
38.4 \\
-\end{array}$ \\
\hline $\begin{array}{l}\text { Sales growth } \\
\text { due to } \\
\text { unchanged } \\
\text { products }\end{array}$ & $\begin{array}{l}\text { Total } \\
\text { Non-innovators } \\
\text { Only process } \\
\text { innovators } \\
\text { Product and process } \\
\text { innovators }\end{array}$ & $\begin{array}{r}-6.16 \\
2.73 \\
4.87 \\
-18.39 \\
\end{array}$ & $\begin{array}{r}-3.88 \\
1.93 \\
\\
3.82 \\
-14.18 \\
\end{array}$ & $\begin{array}{r}-1.34 \\
6.34 \\
11.03 \\
-15.04 \\
\end{array}$ & $\begin{array}{r}0.03 \\
5.25 \\
6.63 \\
-11.90 \\
\end{array}$ & $\begin{array}{r}-8.11 \\
7.54 \\
13.47 \\
-19.59 \\
\end{array}$ & $\begin{array}{r}-5.68 \\
4.65 \\
8.03 \\
-15.63 \\
\end{array}$ & $\begin{array}{c}20.1 \\
38.4 \\
- \\
-49.9\end{array}$ \\
\hline $\begin{array}{l}\text { Sales growth } \\
\text { due to } \\
\text { new products }\end{array}$ & $\begin{array}{l}\text { Total } \\
\text { Non-innovators } \\
\text { Only process } \\
\text { innovators } \\
\text { Product and process } \\
\text { innovators }\end{array}$ & $\begin{array}{r}10.66 \\
0 \\
0 \\
25.43\end{array}$ & $\begin{array}{l}0 \\
0\end{array}$ & $\begin{array}{r}9.65 \\
0\end{array}$ & $\begin{array}{r}0 \\
0 \\
0 \\
0 \\
15.00\end{array}$ & $\begin{array}{r}19.36 \\
0 \\
0 \\
\\
33.70\end{array}$ & $\begin{array}{r}7.91 \\
0 \\
0 \\
0 \\
24.80\end{array}$ & $\begin{array}{c}19.5 \\
0.0\end{array}$ \\
\hline
\end{tabular}

It is worthwhile noticing that whereas the average European firm had a decrease in the sales of old (unchanged) products, non-innovators were still increasing their sales of old products, and process only innovators, i.e. those with new ways of producing the old products without producing any new products, had an even stronger increase in their sales of old products. This phenomenon can easily be explained by the cannibalization of old product sales by new products 
sales. Product and process innovators had thus an even larger decrease in their sales of old products than the average firm. In China, likewise, the sales of old products decreased for product innovators whereas it increased for non-innovators. Conversely, since there can be no sales of new products for non-innovators and process only innovators, the average growth in the sales of new products was higher for the product and process innovators than for all firms on average.

The story is pretty much similar in services (table 3). Innovators in products and processes have higher employment and sales growth rates than process only innovators or non-innovators, and process innovators have higher growth records than non-innovators with the notable exception of Germany. Firms innovating in both products and processes decreased their sales of old products but because of their lower proportion the average firm still saw an increase in its sales of old products. Non-innovators had a higher proportional increase in their sales of old products than the average firm but a less than proportional increase than the process only innovators, again with the exception of Germany. Product innovators increased their sales of new products by more than they decreased their sales of old products. Remember, we only have data for the manufacturing sector for China.

Table 3: Employment level in 2004, and growth in employment and sales (in \%): France, the Netherlands and Germany (2002-2004), in services

\begin{tabular}{|c|c|c|c|c|c|c|c|}
\hline & & \multicolumn{2}{|l|}{ FR } & \multicolumn{2}{|l|}{ NL } & \multicolumn{2}{|l|}{$\mathbf{D E}$} \\
\hline & & mean & median & mean & median & mean & median \\
\hline \multirow{3}{*}{ Employment in 2004} & Total & 442 & 81 & 181 & 50 & 723 & 50 \\
\hline & Total & 10.69 & 3.51 & 3.32 & 0 & 5.86 & 0 \\
\hline & Non-innovators & 11.52 & 3.35 & 2.73 & 0 & 6.10 & 0 \\
\hline \multirow[t]{2}{*}{ Employment growth } & Only process innovators & 11.12 & 3.76 & 4.64 & 1.21 & 0.81 & -1.4 \\
\hline & Product and process innovators & 11.70 & 5.26 & 6.60 & 1.89 & 7.86 & 0.50 \\
\hline \multirow{4}{*}{ Sales growth } & Total & 9.87 & 8.77 & 9.06 & 5.56 & 13.05 & 4.01 \\
\hline & Non-innovators & 8.87 & 8.32 & 7.89 & 4.79 & 12.12 & 1.96 \\
\hline & Only process innovators & 10.67 & 10.03 & 11.11 & 7.55 & 6.68 & 2.36 \\
\hline & Product and process innovators & 12.06 & 9.89 & 14.48 & 9.31 & 19.05 & 8.67 \\
\hline \multirow{4}{*}{$\begin{array}{l}\text { Sales growth due to } \\
\text { unchanged products }\end{array}$} & Total & 3.82 & 5.06 & 4.87 & 3.88 & 0.69 & -0.37 \\
\hline & Non-innovators & 8.87 & 8.32 & 7.89 & 4.79 & 12.12 & 1.96 \\
\hline & Only process innovators & 10.67 & 10.03 & 11.11 & 7.55 & 6.68 & 2.36 \\
\hline & Product and process innovators & -11.89 & -8.23 & -8.86 & -4.68 & -13.03 & -8.18 \\
\hline \multirow{4}{*}{$\begin{array}{l}\text { Sales growth due to } \\
\text { new products }\end{array}$} & Total & 6.05 & $\overline{0}$ & 4.19 & 0 & 12.36 & 0 \\
\hline & Non-innovators & 0 & 0 & 0 & 0 & 0 & 0 \\
\hline & Only process innovators & 0 & 0 & 0 & 0 & 0 & 0 \\
\hline & Product and process innovators & 23.95 & 12.52 & 23.33 & 10.94 & 32.09 & 18.91 \\
\hline
\end{tabular}




\section{Estimates}

Since the data are confidential and only accessible to national researchers, we have estimated equation (1) for each country dataset separately. For the three European countries, additional dummy variables have been introduced to control for size and industry affiliations, and for China, in addition to these dummies we have added five large regions: Bohai Rim, Yangtze River Delta, Pearl River Delta, Middle China and West China, and three ownership dummies: state owned, private and foreign firms. We find that the respective sets of dummy coefficients are statistically significant in all cases and do not report them in the two tables (4 and 5) of estimates.

The growth in sales due to new products (variable $g_{2}$ in equation (1)), is likely to be endogenous, as we explained in section 2. Indeed, a difference-in-Sargan test rejects the null hypothesis of exogeneity in 5 out of 7 cases. We consider that process innovation (variable $d$ ) is sufficiently exogenous as it is not affected by the price mismeasurement ${ }^{5}$. Due to data restrictions, we have instrumented for $g_{2}$ differently for the European and the Chinese data. For Europe, we have used three variables that are contained in the innovation survey: the importance of innovation for explaining the increased range in goods or services produced (RANGE), a dummy variable for doing continuous R\&D (R\&D) and the importance of clients as a source of information for innovation (CLIENT). It is reasonable to believe that these instruments are correlated with product innovation but not with price variations or unanticipated productivity shocks included in the error term. The instruments are found to be strong and valid. ${ }^{6}$ For China, where the endogeneity problem was less acute (exogeneity of $g_{2}$ was not rejected) we have nevertheless resorted to an instrumental variable estimation, using as instruments the dichotomous variables whether R\&D was conducted one and two years before. The overidentifying restriction was not rejected.

\footnotetext{
${ }^{5}$ Harrison et al. (2014) did not find any evidence of endogeneity of process innovation.

${ }^{6}$ The three variables turn out highly significant in almost all cases in the first stage regression where $g_{2}$ is regressed on the exogenous and instrumental variables. The Hansen/Sargan test of overidentifying restrictions does not reject the overidentifying restrictions. Moreover the p-values for the Kleibergen-Paap LM test of underidentification, the Kleibergen-Paap F-test, the Anderson-Rubin Wald test and the Stock-Wright LM tests of weak instruments are always $0.000^{* * *}$ (and hence not reported) indicating that the null hypothesis of weak instruments is rejected. Finally, we have also conducted the difference in Sargan tests when dropping individually each of the instruments. Each variable passes the test of overidentifying restrictions at the $5 \%$ level.
} 
Table 4: Employment Effects of Innovation in Manufacturing, 2002-2004 for France, Germany and the Netherlands, 1999-2006 for China

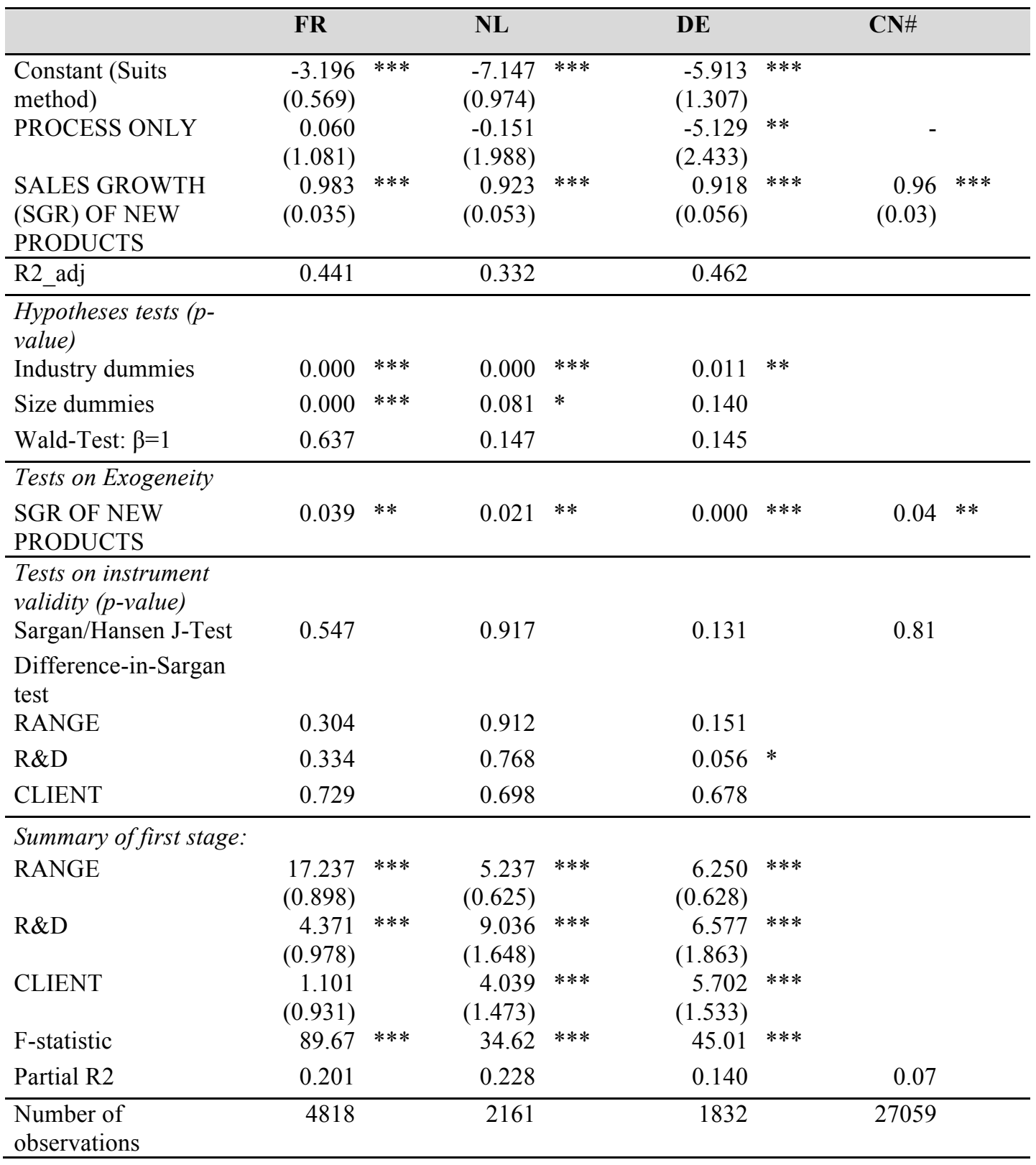

Table 5 Employment Effects of Innovation in Services, in France, Germany and the Netherlands, 2002-2004

\begin{tabular}{|c|c|c|c|}
\hline & FR & $\mathbf{N L}$ & DE \\
\hline Constant (Suits method) & $\begin{array}{l}-3.196 * * * \\
(0.569)\end{array}$ & $\begin{array}{l}-9.854 * * * \\
(0.670)\end{array}$ & $\begin{array}{r}-1.079 \\
(2.124)\end{array}$ \\
\hline PROCESS ONLY & -3.999 & -0.377 & -0.671 \\
\hline
\end{tabular}




\begin{tabular}{|c|c|c|c|c|c|c|}
\hline & $(3.529)$ & & $(1.516)$ & & $(2.990)$ & \\
\hline SALES GROWTH (SGR) & 0.946 & $* * *$ & 0.949 & $* * *$ & 0.838 & $* * *$ \\
\hline OF NEW PRODUCTS & $(0.096)$ & & $(0.059)$ & & $(0.088)$ & \\
\hline R2_adj & 0.334 & & 0.221 & & 0.279 & \\
\hline \multicolumn{7}{|l|}{ Hypotheses tests (p-value) } \\
\hline Industry dummies & 0.641 & & 0.000 & $* * *$ & 0.091 & $*$ \\
\hline Size dummies & 0.008 & $* *$ & 0.063 & $*$ & 0.422 & \\
\hline Wald-Test: $\beta=1$ & 0.570 & & 0.939 & & 0.066 & $*$ \\
\hline \multicolumn{7}{|l|}{ Tests on Exogeneity } \\
\hline SGR OF NEW PRODUCTS & 0.061 & $*$ & 0.015 & $* *$ & 0.427 & \\
\hline \multicolumn{7}{|l|}{$\begin{array}{l}\text { Tests on instrument validity } \\
(p \text {-value) }\end{array}$} \\
\hline Sargan/Hansen J-Test & 0.179 & & 0.997 & & 0.936 & \\
\hline \multicolumn{7}{|l|}{ Difference-in-Sargan test } \\
\hline RANGE & 0.064 & $*$ & 0.950 & & 0.724 & \\
\hline R\&D & 0.220 & & 0.953 & & 0.932 & \\
\hline CLIENT & 0.259 & & 0.980 & & 0.734 & \\
\hline \multicolumn{7}{|l|}{ Summary of first stage: } \\
\hline RANGE & $\begin{array}{l}15.847 \\
(2.441)\end{array}$ & $* * *$ & $\begin{array}{r}5.982 \\
(0.639)\end{array}$ & $* * *$ & $\begin{array}{r}5.550 \\
(0.772)\end{array}$ & $* * *$ \\
\hline \multirow[t]{2}{*}{$\mathrm{R} \& \mathrm{D}$} & 5.069 & & 4.579 & $* * *$ & 13.379 & $* * *$ \\
\hline & $(3.349)$ & & $(1.453)$ & & $(3.097)$ & \\
\hline \multirow[t]{2}{*}{ CLIENT } & 8.978 & $* *$ & 4.248 & $* * *$ & 6.046 & $* * *$ \\
\hline & $(2.830)$ & & $(1.331)$ & & $(2.074)$ & \\
\hline F-statistic & 15.61 & & 25.00 & $* * *$ & 18.32 & $* * *$ \\
\hline Partial R2 & 0.243 & & 0.186 & & 0.190 & \\
\hline Number of observations & 2544 & & 5692 & & 1141 & \\
\hline
\end{tabular}

The results for the three European countries highlight that process innovation does not play a significant role for employment growth. The effect of process innovation related to existing products is only significantly different from zero in German manufacturing firms, where it indicates a lower employment for firms that introduce process innovations. In contrast, product innovation, measured by the sales growth due to new products, significantly affects employment growth in both sectors in all four countries. The $\beta$ coefficient is always smaller than 1 , but significantly so only in German services and there only at the $10 \%$ level of significance. Consequently, we cannot reject the null hypothesis that old and new products are produced with the same level of efficiency. Comparing China with Europe, we find the $\beta$ coefficient remarkably similar across regions. The intercept term indicates that in all instances there has been a general (unrelated to innovation) efficiency change in the production of unchanged products, which has reduced employment.

Our estimation results are largely consistent with those reported in other studies using the same model. The original Harrison et al. paper, only published in 2014 but already circulating as a working paper in 2008, was based on cross-sectional CIS data for 1998-2000 and four countries - France, Germany, Spain and the UK. Hall et al. (2008) estimated the model on Italian firm data 
for the period 1995-1997, 1998-2000, 2001-2003. Dachs and Peters (2014) estimated the model on a panel of $16 \mathrm{EU}$ countries using CIS4 data, and comparing foreign-owned and domesticallyowned firms. A small difference between these papers is in the choice of instruments for the sales growth of new products. Harrison et al. (2014) use the self-declared impact of innovation on the range of products offered. Hall et al. (2008) use "a dummy variable for positive R\&D expenditures in the last year of the 3-year survey period, the same dummy lagged 1 year (in the middle year of the survey period), the R\&D employment intensity in the last year of the survey period, and a dummy variable for whether the firm assigned high or medium importance to developing a new product as the goal of its investment." Dachs and Peters (2014) use the same instruments as we do. In two other contributions to this issue, the same model with some small modifications is estimated in four Latin American countries - Argentina, Chile, Costa Rica and Uruguay - in Crespi et al. and in 53 developing countries in Cirera and Sabetti. Crespi et al. use cross sectional innovation survey data for Argentina and Costa Rica and panel data for Chile and Uruguay. For Costa Rica and Uruguay, they use the same instrumental variables as Harrison et al. (2014). For Argentina, they use the knowledge of public support programs and for Chile the obstacles to innovation averaged at regional levels. Process only innovation has only a negative effect on employment in Uruguay. Cirera and Sabetti decompose process innovation into automated and non-automated process innovation, and they introduce organizational innovation as an additional explanatory variable. As instrumental variables for the growth in sales of new products, they use three dummies indicating respectively whether the product innovation was geared towards extending the market, whether the firm invested in $R \& D$, and whether the innovation was completely new to the firm. They used the World Bank 2013-2015 World Enterprise Survey.

The negative effect on employment due to the general efficiency improvement in the production of the unchanged products comes out in all the studies. A significant effect of process innovation on employment growth is only reported by Harrison et al. (2004) for Germany and the UK manufacturing and by Dachs and Peters (2014) for non-group domestically-owned firms and for non-EU foreign-owned firms. In all other cases, process innovation does not significantly reduce employment, as was initially suspected. A higher efficiency in the production of old as compared to new products is only found by Dachs and Peters (2014) for non-group domestically-owned firms. In all other cases the estimated $\beta$ coefficient is not different from 1 .

\section{Labor growth decomposition}

Regarding the effect of innovation on employment, the results are best explained in terms of a decomposition of employment growth into the various effects identified by our model and 
estimated using the micro data from production, R\&D and innovation surveys. We can decompose the growth in employment in the following way using equation (1):

$l=\hat{\alpha}_{0}+\hat{\alpha}_{1} d+\left(1-1_{g_{2}>0}\right) g_{1}+1_{g_{2}>0}\left(g_{1}+\hat{\beta} g_{2}\right)+v$,

where $1_{g_{2}>0}$ is an indicator taking value 1 when the subscript holds and zero otherwise. The first term captures the change in employment due to industry- and size-specific general productivity growth in the manufacturing of old products (i.e. including the effects of size and industry dummies and in China also region- and ownership dummies), the second term the additional effect due to process innovations, the third term the employment contribution stemming from the output growth in old products by non-product innovators (non-innovators and process only innovators) and the last one the net contribution of product innovation which can be split into the effect resulting from decreased output of unchanged products and increased output of new products.

In the three European countries, the same pattern prevails. In manufacturing, employment grew by $1.8 \%$ between 2002 and $2004^{7}$ in Germany and dropped in France and the Netherlands. Three forces dragged down employment growth: the incidence of process innovation, which accounted for only a small portion of the decrease, the overall productivity growth in the manufacturing of old products, which was especially marked in the Netherlands, and the reduction in the production of old products by product innovators, which dominated the expansion in the production of old products by non-innovators and process-only innovators. The latter was very important in France and Germany. These three negative forces were counterbalanced by one important positive effect: the increase in employment due to the sales accounted for by new products, i.e. products introduced in the last three years. In services, the pattern was slightly different: employment grew in all three countries, despite the recession. In services, the negative productivity effect was smaller than in manufacturing; it even went in the opposite direction in France. The expansion in the production of old products increased employment in France and in the Netherlands, even though it was negative for product innovators. The biggest contributor in the accounting for employment growth in services was still the growth due to the production of new products, except in the Netherlands where the increase in the production of old products increased employment by more than the production of new products. But overall, product innovation was less important for employment growth in services than in manufacturing.

For China, we only have data on manufacturing firms. The output increase due to new products had a positive effect on employment; it increased employment by $16.1 \%$ over the period 19992006, which, if converted to a three year increase for comparison with the European results, would correspond to a lower increase due to new products than in the three European countries.

\footnotetext{
${ }^{7}$ If we take another period, the total growth of employment and its components take different values, but the general pattern is also prevalent over time. The 2002-2004 period was one of more modest growth in employment.
} 
The biggest part of the explanation of employment growth was due to the increase in labor productivity (leading to a reduction in employment by 13\%) and the increase in the sales of old products (leading to an increase in employment by $11.6 \%$ ). There was a tremendous growth of production in China during this period driven by the export market and fueled by low wages and a favorable exchange rate. At the same time there was a big increase in labor productivity as Chinese firms enjoyed scale economies and moved up the learning curve. The total employment growth was positive and comparable to the one in Germany from 2002 to 2004, but the reason for it was due not so much to product innovation as to efficiency and the sheer magnitude in the sales of old products. Our results on China are concordant with those reported by Dosi and $\mathrm{Yu}$ (in this issue), who use basically the same micro data but investigate more deeply the sources of demand growth in China and conduct a separate analysis for each 2-digit industry. Brandt et al. (2012) investigate the source of the huge labor productivity growth in Chinese firms, also basically on the same dataset, and show that it is mainly due total factor productivity growth and the net entry of new firms with above average productivity growth. Jaumandreu and Yin (2017) disentangle the contribution of product and process improvements to productivity growth in Chinese manufacturing firms from 1998 to 2008. They find that Chinese firms grew mainly thanks to cost advantages and only modestly because of product advantages. They do not, however, relate the cost and demand advantages to process and product innovations. An important result of theirs is that quality advantages are negatively correlated with cost advantages. It is costly to produce goods of better quality. Somehow their results confirm the relatively low contribution to employment growth that could be assigned to product innovation.

Our estimates do not differ markedly from those reported by Harrison et al. (2014) on German, French, Spanish and the UK firms over the period 1998-2000 as far as the sign of the direction of the various effects is concerned. The magnitudes may differ because the countries may be at different stages of the business cycle, because they may experience different rates of technical change and different rates of product innovation, but the sign of the sources of employment growth are not different from those reported here. The 2002-2004 period was one of more modest growth in employment compared to the period 1998-2000 examined in Harrison et al. (2014).

For Latin America, Crespi et al. (this issue) find a negative effect of productivity in the manufacture of old products for every country except Uruguay, a positive effect from the expansion in sales of old products for Argentina and Chile, but a negative one for Costa Rica and especially for Uruguay, and a strong positive effect of product innovation, especially in Chile and Costa Rica, but almost non-existent in Uruguay. These effects are more sizeable in large firms and in high-tech sectors. The employment growth was larger for skilled than unskilled labor, the main reason being the smaller displacement effect from technological change in the production of old products for skilled than for unskilled labor. 
Table 6: Employment Growth Decomposition in Manufacturing and Services, France, Germany and the Netherlands, 2002-2004, China, 1990-2006

\begin{tabular}{lccccccc}
\hline & \multicolumn{1}{c}{ manufacturing } & \multicolumn{3}{c}{ services } \\
\hline & FR & NL & DE & CN* & FR & NL & DE \\
Employment growth total & -0.6 & -1.8 & 1.8 & 1.6 & 10.7 & 3.3 & 5.9 \\
\hline Decomposed into & & & & & & & -1.8 \\
\hline Productivity trend in production of old products & -3.9 & -7.3 & -6.1 & -13.0 & 3.1 & -5.3 & -0.1 \\
\hline Contribution of process innovations & 0.0 & -0.1 & -0.7 & - & 0.0 & 0.0 & 4.4 \\
\hline $\begin{array}{l}\text { Output growth of old products for non-product } \\
\text { innovators }\end{array}$ & 1.2 & 3.1 & 3.1 & 11.6 & 5.0 & 6.5 & \\
$\quad \begin{array}{l}\text { Thereof for } \\
\text { Non-innovators }\end{array}$ & & & & & & & \\
$\quad$ Process innovators only & 0.7 & 2.1 & 1.6 & 11.6 & 4.0 & 5.5 & 3.9 \\
\hline Net contribution of product innovations & 0.5 & 1.0 & 1.6 & - & 1.0 & 0.9 & 0.4 \\
$\quad \begin{array}{l}\text { Thereof } \\
\text { Output reduction in old products }\end{array}$ & 2.2 & 2.4 & 5.5 & 3.0 & 2.7 & 2.2 & 3.4 \\
$\quad$ & -8.3 & -6.5 & -12.3 & -3.0 & -3.3 & -1.8 & -7.0 \\
\hline
\end{tabular}

*The growth rates over the eight years between 1999 and 2006 have been converted to three-year growth rates by multiplying all the figures for China by $3 / 8$ to make them comparable to the European figures (assuming a constant growth rate over the whole period).

\section{Conclusion}

Using data from the innovation surveys, which distinguish the production of old (and slightly changed) and new (and substantially changed) products, and a simple accounting model that allows to dissociate the growth in employment due to old and new products on the basis of differences in productivity and volumes of production of each of the two types of products, we have estimated the effects of product and process innovations on employment in manufacturing and services firms in France, Germany and the Netherlands and in manufacturing firms in China. 
The data pertain to the period 2002-2004 for the three European countries and to the period 1999-2006 for China. The underlying model is the same, the data are pretty much comparable (although the sample size is way larger for China), and the econometric approach is very similar.

As in other studies using the Harrison et al. (2014) model, among which the Cirera and Sabetti and Crespi et al. papers in this issue, process innovations alone do not explain a lot of the employment growth. This may be due to the poor measurement of process innovation and to the frequent overlap of product and process innovation, and there seems to be little evidence of a strong difference in efficiency in the production of old and new products. As expected, noninnovation related productivity growth in general tends to reduce employment. This was especially so in the case of China, which in the first decade of the new millennium still benefited from a strong catching-up with the main industrialized countries (see also the Dosi et al. paper in this issue). Sales of old (existing) products increased for non-innovators and process only innovators and therefore drove up employment especially in Chinese manufacturing firms over this period and more in services than in manufacturing as France, Germany and the Netherlands. For product innovators the sales of old products declined confirming the existence of cannibalization, but the most important conclusion from our analysis is that the expansion in the production of new products ("new" in the sense of the Oslo Manual, i.e. introduced for the first time by the firm on the market) had a positive effect on employment in all sectors and all countries, exceeding the employment reductions due to cannibalization.

We may thus conclude that product innovations do not jeopardize employment but instead create jobs. The anxiety of innovation destroying jobs in thus not entirely justified, at least not confirmed by a micro-economic analysis of employment growth decomposition into various sources of technological change. The two main caveats to our optimistic conclusion are first, that we have only imperfectly captured the effects on employment of process innovation and nontechnological innovations, and secondly that we have not considered the secondary effects of innovation on employment in other firms of the same industry as well as in other industries and in countries, in particular in less developed countries.

\section{References}

Brandt, L., J. Van Biesebroeck and Y. Zhang (2012), "Creative accounting or creative destruction? Firm-level productivity growth in Chinese manufacturing", Journal of Development Economics, 97, 339-351 
Benavente, J.M. and R. Lauterbach (2008), "Technological innovation and employment: complements or substitutes?", European Journal of Development Research, 20(2), 318-329.

Bianchini, S. and G. Pellegrino (2017), "Innovation persistence and employment dynamics”, IEB working paper $2017 / 03$.

Calvino, F. and M.E. Virgillito (2018), "The innovation-employment nexus: a critical survey of theory and empirics", Journal of Economic Surveys, 32(1), 83-117.

Crespi, G., E. Tacsir and M. Pereira (2018), "Effects of innovation on employment in Latin America", this issue

Dachs, B. and B. Peters (2014), "Innovation, employment growth, and foreign ownership of firms: A European perspective", Research Policy, 43(1), 214-232.

Dosi, G. and X. Yu (2018), “Technological catch-up, sales dynamics, and employment growth: Evidence from Chinese manufacturing firms", this issue

Evangelista, R. and A. Vezzani (2012), "The impact of technological and organizational innovations on employment in European firms", Industrial and Corporate Change, 21(4), 871899.

Frey, C.B. and M.A. Osborne (2017), “The future of employment: How susceptible are jobs to computerization”, Technological Forecasting and Social Change, 114, 254-280.

Hall, B., F. Lotti and J. Mairesse (2008), "Employment, innovation, and productivity: evidence from Italian microdata", Industrial and Corporate Change, 17(4), 813-839.

Harrison, R., Jaumandreu, J., Mairesse, J., Peters, B. (2014), 'Does innovation stimulate employment? A firm-level analysis using comparable micro-data from four European countries,' International Journal of Industrial Organization, 35, 29-43.

Jaumandreu, J. and H. Yin (2017), "Cost and product advantages: A firm-level model for the Chinese exports and industry growth", CEPR discussion paper 11862.

Lachenmeier, S. and H. Rottmann (2011), "Effects of innovation on employment. A dynamic panel analysis", International Review of Industrial Organization, 29(2), 210-220.

Mairesse J., Y. Wu, Y. Zhao and F. Zhen (2012), "Employment Growth and Innovation in China: A Firm Level Comparison across Regions, Industries, Ownership Types and Size Classes", CREST mimeo paper

Peters, B., B. Dachs, M. Dünser, C. Köhler and C. Rammer (2014), Firm Growth, Innovation and the Business Cycle, Number 110577, ZEW. 
Peters, B. and C. Rammer (2013), "Innovation Panel Surveys in Germany", in: Gault, F. (ed), Handbook of Innovation Indicators and Measurement, Edward Elgar, Cheltenham and Northampton, 135-177.

Pianta, M. (2005), "Innovation and employment", in J. Fagerberg, D. Mowery and R.R. Nelson (eds), Handbook of Innovation. Oxford: Oxford University Press, 568-598.

Ugur, M., S. A. Churchill and E. Solomon (2018), "Technological innovation and employment in derived labour demand models: A hierarchical meta-regression analysis", Journal of Economci Surveys, 32(1), 50-82.

Vivarelli, M. (2014), "Innovation, employment and skills in advanced and developing countries: A survey of economic literature," Journal of Economic Issues, 48, 123-154. 